\title{
Features of concentrate feeding in an automatic milking system with free cow traffic
}

\author{
Delyus Sharipov ${ }^{1 *}$, Oleg Yakimov ${ }^{1}$, Firaya Akhmetzyanova ${ }^{1}$, and Ildar Galimullin ${ }^{2}$ \\ ${ }^{1}$ Kazan State Academy of Veterinary Medicine named after N. E. Bauman, 420029 Kazan, Russia \\ ${ }^{2}$ Commercial farm "Mukhametshin Z. Z.", 422066 Sabinsky district, Republic of Tatarstan, Russia
}

\begin{abstract}
The objective of this research was to study the main factors influencing the consumption of concentrate depending on the daily milk yield in an automatic milking system (AMS) with free cow traffic. The researchers obtained data by visiting AMS from 227 lactating Holstein dairy cows for 30 days. For a more complete characterization of milking activity and feeding concentrate during milking in the AMS, the cows were divided into 6 groups: with a milk yield less than $20.0 \mathrm{~kg}, 20.1-25.0,25.1-30.0,30.1-35.0$, $35.1-40.0$ and more than $40.1 \mathrm{~kg}$ per day. With an increase in milk production, the allocation of concentrate in the milking box increases $(\mathrm{P}<0.001)$. So, with a daily milk yield of $17.6 \pm 0.5 \mathrm{~kg}, 4.93 \pm 0.13 \mathrm{~kg}$ of concentrate was allocated, $23.0 \pm 0.3 \mathrm{~kg}-6.10 \pm 0.11 \mathrm{~kg}$ of, $27.9 \pm 0.2 \mathrm{~kg}-6.93 \pm 0.09 \mathrm{~kg}, 32.7 \pm 0.2-$ $7.50 \pm 0.15 \mathrm{~kg}, 37.3 \pm 0.3-7.68 \pm 0.29 \mathrm{~kg}$ and with a daily milk yield of $42.9 \pm 0.4 \mathrm{~kg}$ allocated $8.00 \pm 0.30 \mathrm{~kg}$ of concentrate. Wherein, the milking frequency between groups increases from $2.9 \pm 0.1$ to $3.1 \pm 0.1$ times a day. Box-visiting time has a significant impact on the consumption of concentrate. So, when visiting a milking box with a duration of $6.09 \pm 0.42 \mathrm{~min}$, cows consumed $4.53 \mathrm{~kg}$ of concentrate, with $6.96 \pm 0.27 \mathrm{~min}(\mathrm{P}<0.05)$ $-5.89 \mathrm{~kg}, 7.09 \pm 0.22 \min (\mathrm{P}<0.05)-6.51 \mathrm{~kg}, 7.25 \pm 0.26 \min (\mathrm{P}<0.05)-6.83 \mathrm{~kg}, 8.06 \pm 0.40 \mathrm{~min}$ $(\mathrm{P}<0.01)-7.08 \mathrm{~kg}$ and when the duration of the visit was $8.07 \pm 0.31 \mathrm{~min}(\mathrm{P}<0.01)$, animals consumed $7.39 \mathrm{~kg}$ of concentrate. Thus, we found that the cows of all productivity groups did not completely consume the concentrate allocated in AMS.
\end{abstract}

\section{Introduction}

In accordance with the development strategy of mechanization and automation of animal husbandry in Russia until 2030, increasing the efficiency of dairy cattle breeding will be carried out through the use of innovative technologies. One of these areas is the introduction of automatic milking systems (AMS). The first AMS in Russia was introduced in December 2007 [1]. However, as of 2020, in Russia milking on AMS covers only $1.1 \%$ of cows, while the numbers for 2009 in the USA are $8.0 \%$, and in Europe it is $5.0 \%$. The limiting factor in the introduction of AMSs is their high cost, the need for careful selection of cows during the formation of the herd, as well as the improvement of the feeding system.

Cows in herds equipped with conventional milking parlors obtain all their daily norm of concentrated feed and nutrients from a total mixed ration (TMR). The introduction of an AMS significantly changes not only the milking mode, but also the feeding system of cows, the essence of which is that concentrated feeds are fed not only as part of a partially mixed ration (PMR), but also during milking, and sometimes in additional concentrate self-feeder. At the same time, manufacturers believe that concentrated feed provided during milking is the main incentive to visit the AMS [2] and, as shown in studies [3], gives more motivation than the milking process itself. This indicates that the number of visits to the milking box is positively associated with desire to consume concentrated feed. Therefore, the concept of using concentrate in AMS is to encourage cows to voluntarily visit a milking box. As a result of using this concept, it is assumed that the amount of feed concentrate in AMS can be used to allow for precision feeding and minimize fetching cows [2,4].

At the same time, the problem is that the milking frequency in the AMS depends not only on the composition and amount of the concentrate offered in the milking box, but also on many other factors, such as, for example, farm layout, type of traffic, health condition of the animals (especially lameness and mastitis) [2].

In the Republic of Tatarstan, an AMS with free cow traffic and additional feeding of concentrated feed in milking box has become widespread. In this case, the dairy herd forms one technological group, in which there are cows with different milk production at different stages of lactation. Under these conditions, it is difficult to meet the needs of the animal in concentrated feed and nutrients in accordance with their production [5, 6]. In addition, there is a wide variation between cows in the consumption of concentrate in the milking box [7].

The objective of this research was to study the main factors influencing the consumption of concentrate

Corresponding author: abdu10401@ rambler.ru 
depending on the daily milk yield in an AMS with free cow traffic.

\section{Material and methods}

A total of 227 lactating Holstein dairy cows (days in milk (DIM) $126 \pm 6.4$ (mean $\pm \mathrm{SE}$ ); 80 primiparous cows, 147 multiparous cows) were kept on a commercial farm "Mukhametshin Z.Z." (Sabinsky district, Republic of Tatarstan, Russia). On this farm, 2 groups approximately 114 lactating cows in each group were placed in separate sections. Husbandry conditions were similar for all cows. In each group, the cows were milked by 2 single-box AMS (Astronaut A4, Lely Industries N.V., Maassluis, the Netherlands). The vacuum level was $48 \mathrm{kPa}$ and the pulsation ratio was 65:35.

Water and a PMR were available ad libitum. The frequency delivery of PMR was three times a day (at 07:30, 11:00 and 15:30). The PMR was composed of $22.0 \mathrm{~kg}$ of corn silage, $10.0 \mathrm{~kg}$ of alfalfa haulage, $1.5 \mathrm{~kg}$ of straws grain crops, $1.7 \mathrm{~kg}$ of grain molasses, $4.0 \mathrm{~kg}$ of concentrates (ground grain), $1.0 \mathrm{~kg}$ of protected protein "Promatrix AST +", $0.3 \mathrm{~kg}$ of protected protein "Belkoff $\mathrm{M}$ " and $0.2 \mathrm{~kg}$ of minerals. Nutrient composition of the PMR: $15.5 \%$ crude protein (CP), $81.8 \mathrm{~g}$ intestine digestible protein (DVE), $21.4 \mathrm{~g}$ degradable protein balance (OEB), $20.7 \%$ crude fiber, $41.1 \%$ neutral detergent fiber (NDF), $3.2 \%$ crude fat (CF) and 854.8 feed unit milk (VEM) kg/of dry matter (DM).

Not eaten residues of the PMR of the previous day were removed daily from the feed bunk at 7:15 in the morning.

With high milk production, the needs for providing energy and protein to dairy cows by feeding additional concentrate in milking boxes increases, the ingredient and nutrient composition of the concentrate are presented in table 1 .

Table 1. Ingredient and nutrient composition of the concentrate offered in AMS

\begin{tabular}{|l|c|}
\hline \multicolumn{1}{|c|}{ Item } & Content \\
\hline Ingredient, \% & \\
Barley grain, ground & 35 \\
Corn grain, ground & 15 \\
Oats grain, ground & 15 \\
Peas grain, ground & 20 \\
Rape cake & 15 \\
Nutrient composition & \\
CP, \% of DM & 17.8 \\
DVE, g of DM & 102.1 \\
OEB, g of DM & 21.3 \\
Crude fiber, \% of DM & 7.9 \\
NDF, \% of DM & 15.0 \\
CF, \% of DM & 3.8 \\
VEM, of DM & 1149.2 \\
\hline
\end{tabular}

All cows had free access to the AMS $22 \mathrm{~h} / \mathrm{d}$ (in total 2 hours was dedicated to cleaning of the system). Cows were granted milking permission after 4.5 hours from previous milking, unless a milking failure occurred, in which case cows would be granted permission to be milked again immediately. A cow would be brought to
AMS for milking if time since the last milking is longer than 8 hours.

During the study, feed samples (ingredients in PMR and AMS concentrate) were taken and sent to Troyw Nutrition (Liski, Voronezh Region, Russia) for chemical analysis.

The daily norm of the allocated concentrate at the milking box was calculated for each cow, based on its milk production and current stage of lactation, using the nutritional module of the herd management system (T4C - Time for Cows, Lely Industries N.V., Maassluis, the Netherlands).

Data such as milking frequency, daily milk yield per cow $(\mathrm{kg})$, box-visiting time per milking (the time spent by every cow on milking processes in every milking, including entry in the AMS, udder cleaning, cluster attachment, sealing of teat, and exit) (min), as well as the daily norm of the allocated concentrate $(\mathrm{kg})$, the daily consumption of concentrate $(\mathrm{kg})$ and the remaining concentrate $(\mathrm{kg})$ at each visit to the milking box were monitored for 30 days using the herd management system "T4C - Time for Cows".

The AMS recorded the amount of concentrate allocated to each cow and was equipped with a device for weighing individual concentrate leftovers. Deviating observations caused by registration errors were excluded from the data set. The Microsoft Excel (Microsoft Corporation, Redmond, WA) program was used for statistical analysis of data obtained during the study. Results are expressed as mean \pm standard error of the mean. Comparisons between the means were evaluated using Student's t-test. A probability of less than 0.05 was considered significances $(\mathrm{P}<0.05)$.

\section{Results and discussion}

For a more complete characterization of milking activity and feeding during milking in the AMS, we carried out a comparative analysis when ranking cows for daily milk yield. For this purpose, cows were divided into 6 groups: with milk yield less than $20.0 \mathrm{~kg}, 20.1-25.0,25.1-30.0$, $30.1-35.0,35.1-40.0$ and more than $40 \mathrm{~kg}$ per day (table 2).

The generally accepted feeding strategy in AMS is that concentrates during milking begin to be fed from a low level at the beginning of lactation, followed by a linear increase as the daily milk yield increases, and then, after a decrease in the daily milk yield, the feeding of the concentrate decreases [8].

As expected, in our studies, with an increase in milk production, the allocation of concentrate in the milking box increases $(\mathrm{P}<0.001)$. So, with a daily milk yield of $17.6 \pm 0.5 \mathrm{~kg}$ per cow, $4.93 \pm 0.13 \mathrm{~kg}$ per day of concentrated feed was allocated, with a daily milk yield of $23.0 \pm 0.3 \mathrm{~kg}$ per cow $-6.10 \pm 0.11 \mathrm{~kg}$ per day of concentrate, $27.9 \pm 0.2 \mathrm{~kg}$ per cow $-6.93 \pm 0.09 \mathrm{~kg}$ per day, $32.7 \pm 0.2-7.50 \pm 0.15 \mathrm{~kg}$ per day, $37.3 \pm 0.3-$ $7.68 \pm 0.29 \mathrm{~kg}$ per day and with a daily milk yield of $42.9 \pm 0.4 \mathrm{~kg}$ per cow, the herd management system "T4C - Time for Cows" allocated $8.00 \pm 0.30 \mathrm{~kg}$ per day of concentrated feed. The statistical analysis of the study 
results showed that daily milk yield had a significant effect on the amount of concentrate allocated $(\mathrm{P}<0.001)$. Wherein, the milking frequency between groups increases from $2.9 \pm 0.1$ to $3.1 \pm 0.1$ times a day. An earlier study [9] did not establish differences in the milking frequency when feeding 1.5 and $7 \mathrm{~kg}$ per day of concentrate in the AMS. There were no differences in the frequency of voluntary milking in studies [10], where 3 and $8 \mathrm{~kg}$ of concentrated feed per day was fed during milking. Compared to other studies on the milking frequency in AMS, the milking frequency we observed was high. The closest milking frequency was in the study [11], where an average of 3.0 milking of day was observed in a free cow traffic system.

Table 2. Characteristic for milking activity and feeding at milking in AMS

\begin{tabular}{|c|c|c|c|c|c|c|c|}
\hline \multirow{3}{*}{$\begin{array}{l}\text { Group of cows by } \\
\text { daily milk yield, } \mathrm{kg}\end{array}$} & \multicolumn{7}{|c|}{ Variable, mean $\pm \mathrm{SE}$} \\
\hline & \multirow{2}{*}{$\begin{array}{l}\text { Daily milk } \\
\text { yield per } \\
\text { cow, kg }\end{array}$} & \multirow{2}{*}{$\begin{array}{l}\text { Milking } \\
\text { frequency }\end{array}$} & \multirow{2}{*}{$\begin{array}{c}\text { Box-visiting } \\
\text { time per } \\
\text { milking, min }\end{array}$} & \multicolumn{3}{|c|}{ Concentrate:, kg } & \multirow{2}{*}{$\begin{array}{c}\text { Concentrate } \\
\text { consumption } \\
\text { rate, g/min }\end{array}$} \\
\hline & & & & allocated & consumed & leftover & \\
\hline$\geq 20.0(\mathrm{n}=15)$ & $17.6 \pm 0.5$ & $2.9 \pm 0.1$ & $6.09 \pm 0.42$ & $4.93 \pm 0.13$ & $4.53 \pm 0.10$ & $0.41 \pm 0.12$ & $277.5 \pm 20.4$ \\
\hline $20.1-25.0(\mathrm{n}=28)$ & $23.0 \pm 0.3$ & $3.0 \pm 0.1$ & $6.96 \pm 0.27$ & $6.10 \pm 0.11$ & $5.89 \pm 0.11$ & $0.22 \pm 0.03$ & $294.3 \pm 9.5$ \\
\hline $25.1-30.0(\mathrm{n}=60)$ & $27.9 \pm 0.2$ & $3.0 \pm 0.1$ & $7.09 \pm 0.22$ & $6.93 \pm 0.09$ & $6.51 \pm 0.10$ & $0.41 \pm 0.07$ & $320.8 \pm 8.3$ \\
\hline $30.1-35.0(\mathrm{n}=61)$ & $32.7 \pm 0.2$ & $3.1 \pm 0.1$ & $7.25 \pm 0.26$ & $7.50 \pm 0.15$ & $6.83 \pm 0.15$ & $0.67 \pm 0.10$ & $318.0 \pm 8.4$ \\
\hline $35.1-40.0(\mathrm{n}=32)$ & $37.3 \pm 0.3$ & $3.1 \pm 0.1$ & $8.06 \pm 0.40$ & $7.68 \pm 0.29$ & $7.08 \pm 0.25$ & $0.61 \pm 0.13$ & $300.7 \pm 12.1$ \\
\hline $40.1 \leq(n=31)$ & $42.9 \pm 0.4$ & $3.1 \pm 0.1$ & $8.07 \pm 0.31$ & $8.00 \pm 0.30$ & $7.39 \pm 0.27$ & $0.60 \pm 0.13$ & $300.3 \pm 11.4$ \\
\hline
\end{tabular}

With an increase in daily milk yield, the consumption of concentrate in the milking box increased from $4.53 \pm$ 0.10 to $7.39 \pm 0.27 \mathrm{~kg} / \mathrm{cow} / \mathrm{d}(\mathrm{P}<0.001)$. This was not unexpected, since an increase in milk production is associated with an increase in nutrient intake, particularly energy and protein, to produce milk [12].

We found that an increase in the consumption of concentrate in the milking box and milking frequency is associated with an increase in daily milk yield. However, not in all productivity groups of cows the consumption of concentrate in the milking box and milking frequency increases simultaneously.

Several studies $[10,13,14]$ reject this conclusion, indicating that greater amount of concentrated feed offered in the AMS does not improve milking frequency or milk production.

The rate of consumption of concentrate in the AMS was $277.5 \pm 20.4-320.8 \pm 8.3 \mathrm{~g} / \mathrm{min}$. We have not established the effect of the amount of fed concentrate on the consumption rate. A number of authors also indicate that the consumption rate of concentrated feed (pellets) is in the range of $250-400 \mathrm{~g} / \mathrm{min} \mathrm{[15],} \mathrm{the}$ average consumption rate in the AMS of $300 \mathrm{~g} / \mathrm{min}$ [16].

The results of the study show that a significant impact on the consumption of concentrated feed has a box-visiting time. So, when visiting a milking box with a duration of $6.09 \pm 0.42 \mathrm{~min}$, cows consumed $4.53 \mathrm{~kg}$ of concentrate, with $6.96 \pm 0.27 \min (\mathrm{P}<0.05)-5.89 \mathrm{~kg}$, $7.09 \pm 0.22 \mathrm{~min}(\mathrm{P}<0.05)-6.51 \mathrm{~kg}, 7.25 \pm 0.26 \mathrm{~min}$ $(\mathrm{P}<0.05)-6.83 \mathrm{~kg}, 8.06 \pm 0.40 \mathrm{~min}(\mathrm{P}<0.01)-7.08 \mathrm{~kg}$ and when the duration of the visit was $8.07 \pm 0.31 \mathrm{~min}$ $(\mathrm{P}<0.01)$, animals consumed $7.39 \mathrm{~kg}$ of concentrated feed in the milking box.

Thus, we found that the cows of all productivity groups did not completely consume the concentrate allocated in AMS. The least amount of not consumed concentrate was in the group of cows with productivity of $20.1-25.0 \mathrm{~kg}$ and amounted to $0.22 \pm 0.03 \mathrm{~kg} / \mathrm{cow} / \mathrm{d}$. The leftover of the concentrate in the amount of $0.41 \mathrm{~kg} / \mathrm{cow} / \mathrm{d}$ was detected in groups of cows with productivity less than $20.0 \mathrm{~kg}$ and $25.1-30.0 \mathrm{~kg}$. The largest leftover of not consumed concentrated feed in
AMS was found in groups of cows with a daily milk yield of more than $30.1 \mathrm{~kg}-0.60 \pm 0.13-0.67 \pm 0.10$ $\mathrm{kg} / \mathrm{cow} / \mathrm{d}$.

An earlier studies [17, 18] show that there were attempts to use AMS for feeding, without milking animals, but this led to a decrease in the effectiveness of the use of AMS. Moreover, feeding a large amount of the concentrate can cause metabolic disturbances and digestive problems.

Studies [19] showed that the minimum amount of concentrated feed fed to the AMS was $0.9 \mathrm{~kg}$ per day, while studies [20] shown that the maximum level of concentrate being offered in the AMS is $11.3 \mathrm{~kg}$ per day. But with an individual approach higher norms for concentrate feeding are applicable, if the cow continues to respond to an increase in the proposed concentrate by increasing production, no digestive problems arise. In an individual approach, the cow's response is continuously evaluated and the norm is automatically reduced if response decreases.

The allocation of large doses of concentrate in AMS increased the variation in the consumption of concentrate in AMS, and as a result, reduced nutrient intake through the concentrate. The standard deviation for mean consumption of concentrate in the milking box increased from 0.39 to $1.49 \mathrm{~kg}$ per day, when the allocated of concentrate in the milking box increased from $4.93 \pm 0.13$ to $8.00 \pm 0.30 \mathrm{~kg}$ per day. Other studies also report that with an increase in the allocation of concentrated feed in the AMS, the standard deviation for mean consumption of concentrate in the AMS increases. So, when allocated $0.5 \mathrm{~kg}$ of concentrate in the AMS, the standard deviation for mean was $0.07 \mathrm{~kg}$ per day [19], with the allocated of $6.0 \mathrm{~kg}$ of concentrate in the AMS, standard deviation for mean was $0.85 \mathrm{~kg}$ per day [21].

In all productivity groups of cows, there are large differences in the individual doses of the allocated concentrate (table 3). In this study, it can be seen that the differences in individual doses of the concentrate delivered is from 0.3 to $10.0 \mathrm{~kg}$ per day. So, if the maximum daily doses concentrate $(7.25-10.0 \mathrm{~kg}$ per day) are greatly influenced by the daily milk yield, then 
minimum values of the concentrated feed allocated $(0.30-1.61 \mathrm{~kg}$ per day) depend more on the stage of lactation.

In addition, it can be assumed that the maximum individual differences may be even greater if there are no restrictions on the allocation of concentrate. It should be noted that in the literature there was no evidence in favor of the positive effect of feeding large doses of concentrated feed at an AMS.

Table 3. Daily differences of the allocated concentrate in AMS

\begin{tabular}{|c|c|c|c|c|c|}
\hline \multirow{2}{*}{$\begin{array}{c}\text { Group of cows by } \\
\text { daily milk yield, kg }\end{array}$} & Mean & SE & Cv, \% & Minimum & Maximum \\
\cline { 2 - 6 } & 4.93 & 0.13 & 10.5 & 1.61 & 7.25 \\
\hline$\geq 20.0(\mathrm{n}=15)$ & 6.10 & 0.11 & 9.8 & 1.20 & 8.35 \\
\hline $20.1-25.0(\mathrm{n}=28)$ & 6.93 & 0.09 & 10.3 & 0.30 & 8.42 \\
\hline $25.1-30.0(\mathrm{n}=60)$ & 7.50 & 0.15 & 15.5 & 1.20 & 10.0 \\
\hline $30.1-35.0(\mathrm{n}=61)$ & 7.68 & 0.29 & 20.9 & 0.60 & 10.0 \\
\hline $35.1-40.0(\mathrm{n}=32)$ & 8.00 & 0.30 & 20.7 & 0.90 & 10.0 \\
\hline $40.1 \leq(\mathrm{n}=31)$ & & & & & \\
\hline
\end{tabular}

Thus, it should be noted that when cows are being fed large doses of concentrate in AMS, it does not guarantee its high consumption, since other factors, such as the milking frequency and box-visiting time, have a great influence. At the same time, the density and particle size, nutrient composition and taste of the concentrate can also affect its consumption in AMS [22-25]. However, these factors have not been studied in this study.

Analysis of the cost of concentrates per $\mathrm{kg}$ of milk shows that a decrease in daily milk yield leads to an increase in the cost of concentrates (Figure 1).

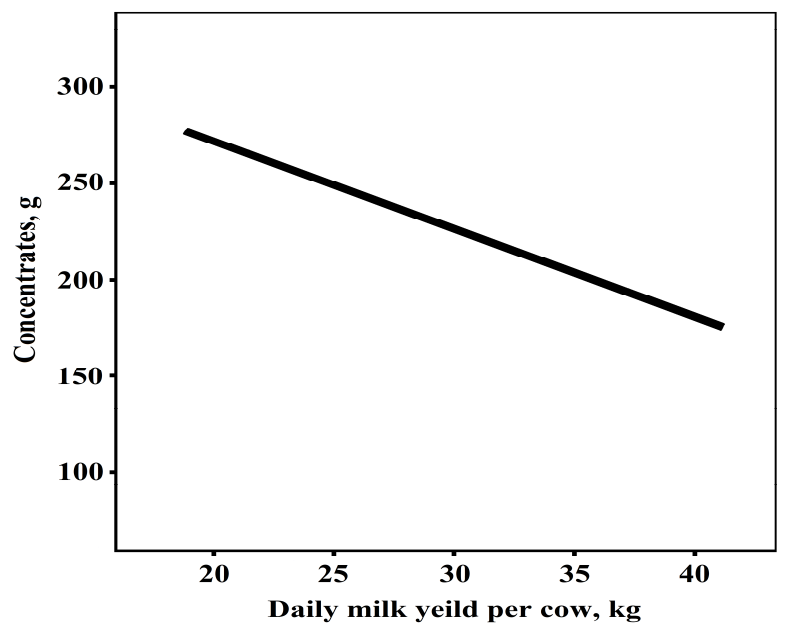

Fig. 1. Cost of concentrates per $\mathrm{kg}$ of milk

It was found that in the group of cows over $40.1 \mathrm{~kg}$ of milk, the cost concentrates per kg of milk is $178.4 \pm 7.3 \mathrm{~g}$, while in the group of cows with milk yield less than $20.0 \mathrm{~kg}-264.9 \pm 6.0 \mathrm{~g}$. Therefore, to maintain the interest of cows in the AMS, an increase in the cost of concentrates per $\mathrm{kg}$ of milk is required. This result is consistent with studies [26] where it was found that in herds with high milk yield and low variation in productivity, it is possible to successfully reduce the amount of concentrate fed to the AMS. Conversely, in herds with a greater variation in milk production may require a higher volume of concentrates to keep the lowyielding cows attracted to the AMS [26].
Nevertheless, the curve of Figure 1 confirms that high-yielding cows are limited in time during their stay in the AMS and are not able to consume all the concentrate released by the herd management system "T4C - Time for Cows". For this reason, feeding concentrated feed in AMS for cows may not be sufficient for the manifestation of genetically incorporated productivity.

Therefore, it can be assumed that this condition can be achieved when the concentrates are simultaneously fed as part of a PMR, during milking and concentrate self-feeding. This assumption should be verified in our future research.

\section{Conclusion}

Results from the current study highlight that with the use of AMS with free cow traffic and additional feeding with concentrated feed only in the milking box, there are restrictions on the consumption of concentrated feed in the AMS. A significant impact on the consumption of concentrated feed had a box-visiting time. In turn, this limitation reduces the animals the production of nutrients and energy and, in turn, reduces the manifestation of their genetic potential. Consequently, this can lead to a decrease in milk production on farms, the effectiveness of the use of AMS, and farmers can incur losses. Therefore, it is necessary to further study the technology of feeding cows in this system, but using additionally installed concentrate self-feeder.

\section{Conflict of interest}

We confirm that no commercial organization has encountered a conflict of interest with respect to the materials discussed in this scientific article.

\section{Acknowledgments}

The authors acknowledge Farit Mukhametshin and Aizat Zakirov for their technical advice during data collection in the commercial farm "Mukhametshin Z.Z." (Sabinsky district, Republic of Tatarstan, Russia). 


\section{References}

1. D. Sharipov, R. Kayumov, T. Akhmetov, R. Ravilov, F. Akhmetzyanova, BIO Web of Conf., 17, 00036 (2020)

2. J. Rodenburg, Proc. Tri-State Dairy Nutrition Conf., Ft. Wayne, Indiana, USA, 127-136 (2011)

3. N.B. Prescott, T.T. Mottram, A.J.F. Webster, Appl. Anim. Behav. Sci., 57, 23-33 (1998)

4. A. Bach, V. Cabrera, J. Dairy Sci., 100, 7720-7728 (2017)

5. S. Winnicki, V.M. Kosolapov, B. Musielska, T. Kolodziejczyk, R. Glowicka-Woloszyn, V. Romanyuk, J. Zootechn., 10, 9-10 (2010)

6. D. Sharipov, Sh. Shakirov, I. Galimullin, J. Compound feeds, 6, 50-52 (2018)

7. I. Halachmi, E. Shoshani, R. Solomon, E. Maltz, J. Miron, J. Dairy Sci., 89, 3241-3249 (2006)

8. G. Andre, P.B.M. Berentsen, G. van Duinkerken, B. Engel, A.G.J.M.O. Lansink, J. Agric. Sci., 148, 263-276 (2010)

9. I. Halachmi, S. Ofir, J. Miron, J. Anim. Sci., 80, 339-344 (2005)

10. A. Bach, C. Iglesias, S. Calsamiglia, M. Devant, J. Dairy Sci., 90, 5049-5055 (2007)

11. J. Madsen, M.R. Weisbjerg, T. Hvelplund, Livest. Sci., 127, 45-50 (2010)

12. F. Bargo, L.D. Muller, J.E. Delahoy, T.W. Cassidy, J. Dairy Sci., 85, 2948-2963 (2002)

13. K. Hare, T.J. DeVries, K.S. SchwartzkopfGenswein, G.B. Penner, Can. J. Anim. Sci., 98, 399-404 (2018)
14. L. Migliorati, M. Speroni, S. Lolli, F. Calza, Ital. J. Anim. Sci., 4, 221-223 (2005)

15. A.F. Kertz, B.K. Darcy, L.R. Prewitt, J. Dairy Sci., 64, 2388-2391 (1981)

16. U. Osîtis, Dzîvnieku êdinâsana kompleksä skatïjumâ (LLU, Jelgava, 2005)

17. S. Devir, E. Maltz, J.H.M. Metz, Comput. and Electr. in Agricult., 17, 95-110 (1997)

18. A.H. Ipema, Comput. and Electr. in Agricult., 17, 79-94 (1997)

19. K.S. Paddick, T.J. DeVries, K. SchwartzkopfGenswein, M.A. Steele, M.E. Walpole, G.B. Penner, J. Dairy Sci., 102, 2173-2187 (2019)

20. J. Salfer, M. Endres, Proc. 4-State Dairy Nutrition \& Manag. Conf., Dubuque, Iowa, USA, 77-80 (2014)

21. S.B. Menajovsky, C.E. Walpole, T.J. DeVries, K.S. Schwartzkopf-Genswein, M.E. Walpole, G.B. Penner, J. Dairy Sci., 101, 9941-9953 (2018)

22. J. Rodenburg, E. Focker, K. Hand, A Better Understanding of Automatic Milking, 511-512 (2004)

23. E. Spörndly, T. Asberg, J. Dairy Sci., 89, 2188-2199 (2006)

24. J. Madsen, M.R. Weisbjerg, T. Hvelplund, Livest. Sci., 127, 45-50 (2010)

25. L. Migliorati, M. Speroni, S. Lolli, F. Calza, Ital. J. Anim. Sci., 4, 221-223 (2010)

26. M. Tremblay, J.P. Hess, B.M. Christenson, K.K. McIntyre, B. Smink, J. van der Kamp, L.G. de Jong, D. Döpfer, J. Dairy Sci., 99, 3824-3837 (2016) 